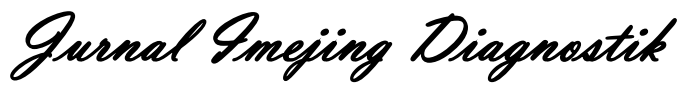

e-ISSN 2621-7457, p-ISSN 2356-301X

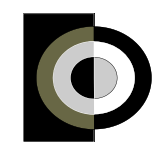

http://ejournal.poltekkessmg.ac.id/ojs/index.php/jimed/index

\title{
Efek Perubahan Dosis Radiasi Dan Kualitas Gambar Pada Hasil Radiograph Dengan Luas Kolimasi Berbeda
}

\author{
Surdiyah Asriningrum \\ Politeknik Al Islam Bandung, Indonesia \\ Corresponding Author: Surdiyah Asriningrum \\ E-mail: surdiyahningrum@gmail.com
}

Received: May $9^{\text {th }}, 2020$; Revised: June 13 ${ }^{\text {th }}, 2020$; Accepted: June $30^{\text {th }}, 2020$

\begin{abstract}
Background: The use of variations of collimation will provide a low dose to the patient and radiographic results that provide a good quality image. This research is to examine the effects of various collimation sizes on the image quality and radiation doses when using $\mathrm{x}$-ray machine at Radiology laboratory of Al-Islam Polytechnic, Bandung. How much the change in density values that occur and to find out of scattering radiation received by the patient in the Radiology laboratory of Al-Islam Polytechnic, Bandung.

Methods: This type of research is an experimental study with participatory observation data collection. at the Radiology Laboratory of the Al-Islam Polytechnic, Bandung The independent variable is variations of collimation, the dependent variables are quality image and doses radiation. Data collection was carried out by exposing a Stepwedge stored on a 35 x $35 \mathrm{~cm}$ radiographic cassette with different irradiation areas and pendose as a measure of radiation. Radiograph results were analyzed by a densitometer. Then the results will be analyzed using digraph to know the movement of each different irradiation field area.

Results: The results showed that there were influences of changes in the variation of collimation. Density value and scattered radiation of each different irradiation field area produces are different values. The smaller area of the irradiation field. Is, the higher density value and low dose. Thus, to get the best density value and the low dose is required to reduce the width of the collimation field conducted.
\end{abstract}

Conclusions: There was an influence variation of collimation on the quality of the image and dose to the patient.

Keyword: Density; Area of irradiation; Stepwedge; Pendose

\section{Pendahuluan}

Sejak ditemukannya sinar-x pada tahun 1895 , pemanfaatan teknologi sinar-x dalam menghasilkan pencitraan gambar mengalami perkembangan yang sangat pesat. Penggunaan digital technology dengan bantuan komputer dan detektor mampu memperoleh dan memproses gambar serta memudahkan jaringan komunikasi untuk mengirim dan menyimpan gambar. Teknologi ini sangat membantu pelayanana kesehatan dalam mendiagnosa suatu penyakit lebih cepat.

Dalam mengahasilkan pencitraan, sinar- $\mathrm{x}$ yang memiliki sifat sebagai radiasi pengion apabila menembus bahan/materi akan terjadi tumbukan foton dengan atom-atom bahan yang menimbulkan ionisasi didalam bahan tersebut, kejadian inilah yang memungkinkan timbulnya efek radiasi terhadap tubuh, baik yang bersifat non stokastik, stokastik maupun efek genetik ( Hidayatulloh, 2017). Oleh karena itu petugas radiologi harus mengusahakan agar dosis pasien yang diterima tetap serendah mugkin yang dapat dicapai (As Low As Reasonably Achievable ALARA), dengan tidak mengurangi kualitas pencitraan.

Penggunaan Sinar-X di bidang Radiologi dengan tujuan medis harus dijaga dengan mempertimbangkan kualitas gambar yang dapat dicapai tanpa mengurangi hasil diagnosa. Salah satu Untuk meningkatkan hasil pencitraan radiograph yaitu dengan membatasi luas lapangan kolimasi. Tujuan dari pembatasan luas lapangan 
kolimasi, yaitu : 1) Mengurangi dosis pasien dan 2) Meningkatkan kontras gambar dengan mengurangi radiasi hambur. Pembatasan luas lapangan kolimasi dapat mempengaruhi kontras citra radiograf, karena kontras radiografi berbanding terbalik dengan radiasi hambur (Bontrager, 2014 ).

Pada penelitian yang dilakukan sebelumnya oleh ( Boddy, 2013 ) untuk mendapatkan kontras yang optimal maka di perlukan penurunan radiasi hambur yang mencapai film. Hal ini dapat diperoleh dengan beberapa cara diantaranya adalah pembatasan penyinaran (kolimasi secukupnya), pemakaian teknik KV rendah, teknik kompresi dan penggunaan grid ( Ball, 1995).

Produksi sinar-x bermula dari katoda (filamen) dipanaskan sampai menyala dengan mengalirkan listrik yang berasal dari transformator sehingga elektron-elektron dari katoda (filamen) terlepas. Sewaktu dihubungkan dengan transformator tegangan tinggi, elektron-elektron akan dipercepat gerakannya menuju anoda dan dipusatkan ke alat pemusat (focusing cup). Filamen dibuat relatif negatif terhadap sasaran (target) dengan memilih potensial tinggi, awanawan elektron mendadak dihentikan pada sasaran (target) sehingga terbentuk panas (>99\%) dan sinar-X $(<1 \%)$. Pelindung (perisai) timah akan mencegah keluarnya sinar-X dari tabung. Sehingga sinar-X hanya keluar melalui jendela. Panas yang tinggi dapat pada sasaran (target) akibat benturan elektron ditiadakan oleh radiator pendingin. Jumlah sinar-X yang dilepaskan setiap satuan waktu dapat dilihat pada alat pengukur miliampere (mA), sedangkan jangka waktu pemotretan dikendalikan oleh alat pengukur waktu.

(Bushong, 2001)

Berdasarkan latar belakang tersebut penulis akan mengkaji pengaruh radiasi hambur yang diakibatkan oleh luas lapangan kolimasi terhadap kualitas citra radiograph dan dosis yang diterima pasien.

\section{Metode}

Jenis penelitian yang digunakan dalam penelitian ini adalah kuantitatip dengan pendekatan eksperimen deskriptif. Dengan variabel bebasnya adalah luas lapangan kolimasi dan variabel terikat kualitas citra gambar ( densitas dan kontras ) dan dosis radiasi, dengan menggunakan step wedge untuk mengetahui nilai densitas kemudian diukur dengan menggunakan densitometer dan pendose untuk mengukur dosis radiasi. Dari hasil masing- masing radiograph kemudian dianalisa secara deskriptif untuk mengetahui pengaruhnya.

\section{Hasil dan Pembahasan}

\section{Pengaruh luas lapangan kolimasi terhadap kualitas citra gambar}

Tabel 1. Nilai Rata rata Densitas pada luas lapangan kolimasi $16 \times 10 \mathrm{~cm}$

\begin{tabular}{ccccc}
\hline \multirow{2}{*}{$\begin{array}{c}\text { Step } \\
\text { wedge }\end{array}$} & \multicolumn{3}{c}{ Nilai Densitas } & Rata-rata \\
\cline { 2 - 4 } & 1 & 2 & 3 & Densitas \\
\hline 1 & 0,72 & 0,72 & 0,72 & 0,72 \\
2 & 0,78 & 0,78 & 0,79 & 0,78 \\
3 & 0,89 & 0,90 & 0,92 & 0,90 \\
4 & 1,07 & 1,09 & 1,12 & 1,09 \\
5 & 1,29 & 1,31 & 1,30 & 1,3 \\
6 & 1,50 & 1,50 & 1,53 & 1,51 \\
7 & 1,74 & 1,76 & 1,76 & 1,75 \\
8 & 1,97 & 1,98 & 1,98 & 1,97 \\
9 & 2,17 & 2,19 & 2,18 & 2,18 \\
10 & 2,35 & 2,37 & 2,38 & 2,36 \\
11 & 2,46 & 2,48 & 2,46 & 2,46 \\
\hline
\end{tabular}

Dari tabel 1 dapat dilihat bahwa pengambilan radiograph menggunakan faktor $60 \mathrm{kV}, 5,6 \mathrm{mAs}$ dengan luas lapangan penyinaran $16 \mathrm{~cm} \mathrm{X} 10 \mathrm{~cm}$ diperoleh hasil densitas pada step 11 sebesar 2,46

Tabel 2. Nilai Rata rata densitas pada luas lapangan kolimasi 24 x $12 \mathrm{~cm}$

\begin{tabular}{ccccc}
\hline \multirow{2}{*}{$\begin{array}{c}\text { Step } \\
\text { wedge }\end{array}$} & \multicolumn{3}{c}{ Nilai Densitas } & Rata-rata \\
\cline { 2 - 4 } densitas
\end{tabular}

Dari tabel 2 dapat dilihat bahwa pengambilan radiograph menggunakan faktor eksposi $60 \mathrm{kV}$, 5,6 mAS dengan luas lapangan penyinaran $24 \mathrm{x}$ $12 \mathrm{~cm}$ diperoleh hasil densitas pada step 11 sebesar 2,50 .

Dari tabel 3 dapat dilihat bahwa pengambilan radiograph menggunakan faktor eksposi $60 \mathrm{kV}, 5,6$ mAs dengan luas lapangan penyinaran $30 \mathrm{X} 13 \mathrm{~cm}$ diperoleh hasil densitas, pada step 11 sebesar 2,57 
Tabel 3. Nilai Rata rata densitas pada luas lapangan kolimasi 35 x $13 \mathrm{~cm}$

\begin{tabular}{ccccc}
\hline \multirow{2}{*}{$\begin{array}{c}\text { Step } \\
\text { wedge }\end{array}$} & \multicolumn{3}{c}{ Nilai Densitas } & $\begin{array}{c}\text { Rata-rata } \\
\text { densitas }\end{array}$ \\
\cline { 2 - 4 } & 1 & 2 & 3 & 0,69 \\
2 & 0,69 & 0,69 & 0,69 & 0,69 \\
3 & 0,69 & 0,69 & 0,70 & 0,74 \\
4 & 0,72 & 0,74 & 0,76 & 0,91 \\
5 & 0,90 & 0,92 & 0,93 & 1,21 \\
6 & 1,18 & 1,23 & 1,24 & 1,47 \\
7 & 1,48 & 1,46 & 1,49 & 1,72 \\
8 & 1,70 & 1,72 & 1,74 & 2,04 \\
9 & 2,03 & 2,03 & 2,06 & 2,38 \\
10 & 2,37 & 2,39 & 2,38 & 2,45 \\
11 & 2,43 & 2,45 & 2,47 & 2,57 \\
\hline
\end{tabular}

Grafik densitas berdasarkan luas lapangan kolimasi, dapat di lihat pada gambar 2 berikut ini :

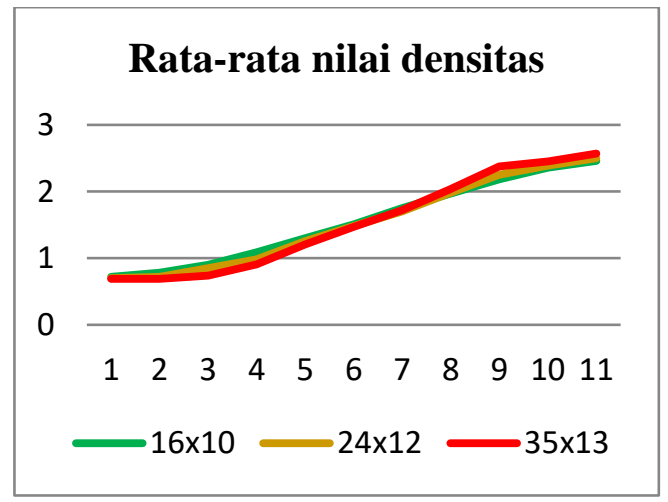

Gambar 2. Grafik densitas radiografi

\section{Nilai Kontras Radiografi}

Nilai kontras film yang dihasilkan terhadap perubahan luas lapangan penyinaran , dapat diambil dari nilai Gradient rata-rata film pada kurva karakteristik film. Sedangkan nilai kontras maksimal didapatkan dengan mencari selisih densitas maksimal dikurangi densitas minimal (Dmaks - Dmin) ( Ball, 1995).

Nilai kontras maksimal dapat dilihat pada tabel berikut :

Tabel 4. Nilai hasil kontras

\begin{tabular}{cc}
\hline Luas lapangan kolimasi & $\begin{array}{c}\text { Hasil nilai kontras } \\
\text { maksimal }\end{array}$ \\
\hline $16 \times 10 \mathrm{~cm}$ & 1,56 \\
$24 \times 12 \mathrm{~cm}$ & 1,8 \\
$35 \times 12 \mathrm{~cm}$ & 1,88 \\
\hline
\end{tabular}

Nilai Kontras maksimum yang paling tinggi adalah luas lapangan penyinaran $35 \mathrm{~cm} \times 12 \mathrm{~cm}$ yaitu 1,88 kontras maksimum yang rendah adalah luas lapangan penyinaran $16 \mathrm{~cm} \times 10 \mathrm{~cm}$ yaitu 1,56 .

\section{Pengaruh Luas Lapangan Kolimasi terhadap Dosis Radiasi}

Tabel 4. Nilai dosis radiasi yang diterima pasien.

\begin{tabular}{ccc}
\hline Luas lapangan & Anoda & Katoda \\
\hline $16 \times 10 \mathrm{~cm}$ & $0 \mu \mathrm{Sv}$ & $0 \mu \mathrm{Sv}$ \\
$24 \times 12 \mathrm{~cm}$ & $0 \mu \mathrm{Sv}$ & $1 \mu \mathrm{Sv}$ \\
$35 \times 12 \mathrm{~cm}$ & $2 \mu \mathrm{Sv}$ & $1 \mu \mathrm{Sv}$ \\
\hline
\end{tabular}

Setelah dilakukan pengeksposan maka pengukuran hasil dosis radiasi menggunakan pendose didapat nilai dosis terbesar yang diterima pasien terdapat pada luas lapangan $35 \times 12 \mathrm{~cm}$ yaitu di titik anoda $2 \mu \mathrm{Sv}$ dan di titik katoda $1 \mu \mathrm{Sv}$.

Perubahan luas lapangan dapat mengakibatkan perubahan densitas dan penurunan terhadap kontras radiografi. Dengan bertambah tambahnya luas lapangan kolimasi maka akan menyebabkan radiasi hambur semakin meningkat.

\section{Simpulan}

Untuk mendapatkan densitas dan kontras yang optimal maka di perlukan penurunan radiasi hambur dengan membatasi luas lapangan penyinaran. Semakin kecil luas lapangan penyinaran, maka dosis radiasi yang diterima pasien semakin rendah.

\section{Daftar Pustaka}

BAPETEN.(2003). Keputusan Kepala Bapeten Nomor 01P/Ka-BAPETEN/I-03 tentang Pedoman Dosis Pasien. Jakarta

Boddy, Syarif Muhammad. (2013). Pengaruh Radiasi Hambur Terhadap Kontras Radiografi Akibat Variasi Ketebalan Obyek dan Luas Lapangan Penyinaran. Repository Hasanuddin University. Di ambil dari http://repository.unhas.ac.id/bitstream/handle/12345678 9/6758/Jurnal\%20Syarif.pdf? sequence $=1$

Bontrager, Kenneth L., \& John P Lampignano. (2014). Text Book of Radiographic Positioning dan Related Anatomy, (8th ed). Missouri:Mosby Company

Bushong, S.C. (2001). Radiologic Science for Technologists, (7th ed). Toronto:Mosby Company

Hidayatulloh, Rahmat. (2017). Dampak Tingkat Radiasi Pada Tubuh Manusia. Jurnal Mutiara Elektromedik, 1, 16-23. Di ambil dari http://e-journal.sarimutiara.ac.id/index.php/Elektromedik/article/download/ 140/157/

Ball, John., \& Tony Price. (1995). Chesneys' Radiographic Imaging (6th ed). Blackwell Science.UK 